\title{
Pendidikan Ramah Anak: Upaya Reposisi Wacana Kemanusiaan dalam Potret Pendidikan Indonesia
}

\author{
Emna Laisa \\ Institut Agama Islam Negeri Madura, Indonesia \\ e2nk.cute@gmail.com
}

\begin{abstract}
Abstrak
Dunia pendidikan merupakan wahana aktualisasi berbagai potensi anak didik. Potensi tersebut senantiasa ditumbuhkembangkan untuk dimanfaatkan secara maksimal dalam kehidupannya. Ungkapan maksimal di sini bukan diaktualisasikan dalam bentuk eksploitasi, pemaksaan dan kekerasan, melainkan diarahkan untuk menciptakan metamorfosis anak didik dari yang biasa menjadi luar biasa. Namun adakalanya makna metamorfosis juga disalahartikan dengan menciptakan model pendidikan yang terlalu berat dijalani anak didik, yaitu kegiatan pendidikan kognitif layaknya kegiatan menabung dan memposisikan anak didik sebagai miniatur orang dewasa. Di sinilah letak urgensi wacana humanisasi melalui thariqah al-dimuqratiyyah aldlaifiyyah (metode pendidikan demokrasi yang luwes) sebagai konsep pendidikan yang memanusiakan manusia. Hal ini mengilhami lahirnya konsep Sekolah Ramah Anak (SRA) guna diaplikasikan dalam lembaga pendidikan, sehingga anak didik merasakan bahwa pendidikan yang dijalaninya adalah wadah yang menampung dan mengapresiasi jiwa mereka.
\end{abstract}

Kata Kunci: aplikasi, kemanusiaan, konsep, sekolah ramah anak 


\begin{abstract}
Education is a vehicle to actualize of the student's potential. The potential is always nurtured to be fully utilized in their life. The focus here is not to actualize in the form of exploitation, exertion and violence but it is directed to create a metamorphosis from the ordinary into the extraordinary. Yet, the word "metamorphosis" misinterpreted to another meaning as creating hard educational models for the students. It seems as cognitive educational activities which shows student's position as adult miniature. Here, the researcher will investigate the importance of discourse humanization as the concept of humanizing education. It's inspire to create a concept of Sekolah Ramah Anak to be applied in educational institutions so that students feel that education is appreciates their souls.
\end{abstract}

Keywords: application, concept, humanity, sekolah ramah anak

\title{
PENDAHULUAN
}

Dewasa ini, merebaknya tindak kekerasan di berbagai lembaga pendidikan menjadi masalah serius dan semakin mencoreng citra pendidikan di Indonesia. Berbagai permasalahan tersebut tampak pada fenomena Juvenile Delinquency, yaitu sebuah bentuk kenakalan remaja yang menjurus pada aktivitas penyerangan, pelanggaran, dan tindak kejahatan yang dilakukan oleh remaja usia di bawah 22 tahun. $^{1}$ Wujud perilaku delinkuen ini antara lain tawuran, bolos sekolah,

\footnotetext{
1 Juvenile berasal dari bahasa latin juvenilis yang berarti anak muda, sifat khas yang terjadi pada periode remaja. Sedangkan delinquent berasal dari bahasa latin delinquere bermakna terabaikan, jahat, asosial, kriminal, pelanggar aturan, pembuat ribut. Juvenile delinquency adalah gejala patologi sosial yang disebabkan oleh pengabaian sosial pada usia anak dan remaja sehingga mereka melakukan tindakan yang menyimpang. Hal ini disebabkan beberapa faktor, antara lain yaitu hidup dalam keluarga tidak harmonis, kekerasan dalam keluarga, tinggal di daerah perkotaan dengan intensitas kriminal tinggi, serta penerapan tindakan pendisiplinan yang tidak berkesinambungan. Lihat, Kartini Kartono, Patologi Sosial 2: Kenakalan Remaja (Jakarta: Rajawali Pers, 2013), 6 .
} 
pemerasan, ancaman, narkoba, pelecehan seksual dan lain sebagainya. Tindakan delinkuen tidak hanya dilakukan secara individu, namun telah merambah dalam sebuah kelompok atau geng. Ironisnya, tindakan brutal tersebut terjadi juga di institusi sekolah.

Di samping itu, menjamurnya lembaga pendidikan yang menawarkan berbagai macam program, seperti sekolah alam, bilingual, kurikulum internasional, kurikulum nasional plus, dan sekolah asrama menawarkan sesuatu yang dianggap idaman bagi anak perspektif orang tua. Namun ada hal yang harus diperhatikan, ideal menurut orang tua, belum tentu ideal bagi anak yang menjalaninya. Memang benar, kurikulum, guru-guru profesional, dan sarana prasarana yang memadai dapat menyokong terciptanya sekolah idaman, namun segala kelebihan tersebut tidak akan berdampak signifikan jika tidak berbanding lurus dengan kebutuhan anak. Karena bagaimanapun anak-anak bukanlah miniatur orang dewasa, ia tumbuh dan berkembang mengikuti alur alamiah yang seharusnya diarahkan, bukan dipaksakan.

Keadaan ini diperparah dengan pemberlakuan sistem pembelajaran yang masih terkesan jauh dari espektasi anak didik. Pembelajaran masih kaku, kurang menyenangkan, dan menerapkan banking concept education (pendidikan konsep bank) dengan memposisikan anak didik sebagai celengan dan pendidik sebagai penabungnya. Padahal tujuan utama pendidikan sebagaimana yang dikemukakan Jean Piaget adalah membantu anak-anak belajar tentang cara belajar, dan bahwa pendidikan seharusnya membentuk pikiran siswa, bukan mengisi 
pikiran siswa dengan berbagai materi pelajaran. ${ }^{2}$ Sejalan dengan itu pula, Paulo Friere mengkritik fenomena pendidikan semacam ini sebagai bagian dari perangkat dehumanisasi. Menurutnya, pendidikan yang didasari sifat egoistik para penindas dengan menjadikan kaum tertindas sebagai obyek humanitarianisme mereka, malah menjelmakan penindasan itu sendiri. ${ }^{3}$

Melihat berbagai fakta di atas, dibutuhkan upaya progresif dari pemangku kebijakan pendidikan nasional untuk menciptakan kultur pendidikan yang aman dan ramah bagi anakanak, tidak hanya dalam tata nilai dan pergaulan, melainkan juga dalam proses transformasi pengetahuan yang semuanya diatur dalam mekanisme internal sekolah. Mekanisme preventif tersebut harus dilakukan sedini mungkin terhadap potensi kekerasan terhadap anak, baik bersifat fisik, non-fisik ataupun kekerasan yang bersifat seksual maupun bersifat verbal.

Tugas untuk mengembalikan pergeseran nilai-nilai kemanusiaan tersebut merupakan hal yang urgen. Orientasi konsep pendidikan perlu direkonstruksi pada pengembangan fitrah dasar manusia secara lebih sistematis dan realistis. Sebab, sesederhana apapun sebuah proses pendidikan, sasaran utamanya harus mengacu pada tujuan yang utama, yakni memanusiakan manusia.

\section{HASIL DAN PEMBAHASAN}

Wacana Kemanusiaan dalam Pendidikan

\footnotetext{
2 J Piaget, Science of Education and The Psychology of The Chil (New York: Viking, n.d.), 70.

3 Paulo Friere, Pendidikan Kaum Tertindas (Jakarta: LP3ES, n.d.), 26.
} 
Istilah kemanusiaan merujuk pada sifat manusia yang berorientasi pada dua tugas pokok, yaitu sebagai pemegang mandat Ilahiah (merujuk pada hubungan manusia dengan Allah), dan mandat kultural (hubungan antar manusia). ${ }^{4}$ Selain itu, nilai kemanusiaan didefinisikan sebagai pengakuan terhadap kemuliaan manusia karena memiliki harkat dan martabat yang terbentuk dari kemampuan kejiwaannya yang digerakkan oleh akal budi yang membedakan dengan makhluk lain. ${ }^{5}$

Pendidikan berwawasan kemanusiaan mengisyaratkan dua muatan, yaitu muatan filosofis dan muatan operasional praktis. Muatan filosofis bersinggungan dengan pembicaraan tentang eksistensi manusia dalam pendidikan. Sedangkan muatan operasional praktis berkenaan dengan bagaimana menciptakan suatu proses pendidikan yang bermuara pada kegiatan dan tujuan yang sakral transendental, yakni memanusiakan manusia. ${ }^{6}$ Pendidikan sebagai instrumen humanitas memiliki lima prinsip yang membuatnya senantiasa dinamis dan

4 Sudarwan Danim, Agenda Pembaruan Sistem Pendidikan (Yogyakarta: Pustaka Pelajar, n.d.), 2.

5 Abd etal Khalik, Pemikiran Pendidikan Islam (Yogyakarta: Pustaka Pelajar, n.d.), 41.

6 Dalam tataran filosofis, pendidikan diposisikan sebagai suatu proses pembinaan dan pengembangan fitrah manusia sesuai dengan nilai-nilai agama. Dalam Islam, manusia dipandang sebagai satu kesatuan jasmaniah dan ruhaniah dan melalui pendidikan Islam kedua dimensi itu dikembangkan secara seimbang. Pada tahap operasinal pendidikan, kegiatan pendidikan dilakukan dengan transfer pengetahuan kognitif dan mengisi hati peserta didik sehingga dapat memperteguh fitrah keimanan serta melatih kemandirian pada peserta didik. kegiatan pendidikan yang tidak memperhatikan keseimbangan antara dua dimensi tersebut merupakan proses pendidikan yang arogan dan bertentangan dengan nilai-nilai humanistik. Lihat, Baharuddin dan Muh. Makin, Pendidikan Humanistik (Konsep, Teori dan Aplikasi Praksis dalam Dunia Pendidikan) (Yogyakarta: ArRuzz Media), 111-112. 
memperhatikan manusia sebagai subjek pendidikan, di antaranya:

Prinsip pertama, manusia adalah pelaku sejarah. Manusia adalah makhluk yang senantiasa melakukan refleksi diri, melihat masa lalu, hingga melakukan perenungan dan penelitian sebagai tindakan koreksi terhadap masa lalu untuk menciptakan produk yang lebih bermutu di era selanjutnya.

Prinsip kedua, manusia adalah makhluk yang unik dengan berbagai sisi individualitasnya. Setiap manusia mempunyai ciri khas tertentu bergantung pada bakat yang dimiliki. Penyelenggaraan pendidikan harus memahami hal-hal tersebut agar terhindar dari ketimpangan dan kesenjangan.

Prinsip ketiga, manusia memerlukan sosialisasi. Berdasar pada pernyataan manusia adalah makhluk sosial, hubungan antar manusia mengisyaratkan relasi saling meminta penerimaan dengan sepenuh hati. Oleh karena itu, dasar hubungan dalam perwujudan eksistensi bersama tersebut didasarkan pada pola hubungan yang egaliter, adil dan pemberian kesempatan untuk mengembangkan diri.

Prinsip keempat, manusia berinteraksi dengan alam sekitar. Manusia sadar bahwa ketersediaan alam belum sepenuhnya sesuai dalam rangka pemenuhan kebutuhan manusia. Oleh karena itu, manusia perlu berusaha mengatasi batasan antara alam dengan dirinya. Tidak cukup hanya dengan mengangkat alam ke tataran manusiawi, namun juga memberdayakan manusia untuk mendidik diri dan menyuarakan kebebasannya.

Prinsip kelima, manusia menemukan Yang Transendental dari proses mengolah alam pikir dan rasa. Relasi antara manusia 
dengan Tuhannya dalam sebuah kepercayaan merupakan langkah besar manusia menuju sumbernya yang pertama dari eksistensi diri dan dunia. Hubungan ini dapat dimanifestasikan dengan melakukan kontemplasi yang direalisasikan melalui doa, kesalehan dan kebaikan. ${ }^{7}$

Lima prinsip kemanusiaan tersebut mengisyaratkan adanya kesinambungan antara hubungan manusia dengan tuhannya, hubungan dengan sesama, dan juga dengan alam sekitar. Hubungan antara manusia dengan Tuhan tampak dalam ritual ibadah, sedangkan hubungan manusia dengan sesama dan alam menunjukkan kedudukan manusia sebagai khalifah yang bertanggung jawab memakmurkan bumi berdasarkan konsep almuhaafdzah 'ala al-qadiim al-shaliih wa al-akhdu bi al-jadid alashlah. $^{8}$

Dengan lima wacana kemanusiaan tersebut pendidikan diterapkan. Dalam ranah aplikasinya, kegiatan pendidikan harus mempertimbangkan beberapa hal penting, di antaranya:

Pertama, menggunakan kritik sebagai metodologi. Dengan demikian, pendidikan memberikan kemungkinan seseorang memiliki kemampuan berpikir yang baik, sehingga dapat merumuskan pokok-pokok pikirannya agar bisa diaktualisasikan. Aktualisasi berarti komunikasi dan memahami kerangka pikir orang lain. Dengan kemampuan berpikir yang disertai daya kritis,

\footnotetext{
7 Tim Penyusun Universitas Sanata Dharma, Transformasi Pendidikan Memasuki Millenium Ketiga (Yogyakarta: Kanisius, n.d.), 22-23.

8 Emna Laisa, "Optimalisasi Pendidikan Agama Islam Di Sekolah Melalui Pengembangan Budaya Religius (Studi Pada SMK Darul Ulum Bungbungan Bluto Sumenep"," Islamuna 3, no. 1 (n.d.): 86-87.
} 
akan terbuka dialog dalam rangka reinterpretasi terhadap dunia demi kelanjutan proses humanisasi manusia.

Kedua, kurikulum yang integratif dan kritis. Berkaitan dengan wacana kemanusiaan, kurikulum harus mempunyai pijakan tentang metode, tujuan, materi, serta evaluasi yang terintegrasi. Kurikulum integratif (integrated curriculum) menghapus batas antar mata pelajaran dan menyiapkan pelajaran dalam bentuk unit atau kesatuan. Tata laksana kurikulum ini mendasarkan diri pada sistem pembelajaran yang berpusat pada minat anak yaitu bersifat life centered (berhubungan dengan kehidupan).

Ketiga, relasi transformatif antara guru dan siswa. Dalam praktik pendidikan, guru dan siswa merupakan manusia yang terlibat secara langsung, keduanya adalah pelaku pendidikan yang menentukan berhasil tidaknya sebuah penyelenggaraan pendidikan. Rancangan pendidikan secanggih apapun tidak banyak bermakna tanpa kesanggupan keduanya untuk melaksanakan agenda pendidikan dan menghadapi setiap tantangan yang ada. ${ }^{9}$

Pola relasi guru dan siswa harus berjalan secara seimbang tanpa adanya dominasi guru secara mutlak. Peserta didik juga memiliki kebebasan mengembangkan seluruh kekuatan intelegensinya. Hasan Langgulung berpendapat bahwa manusia telah dipersiapi dengan kemauan yang mendorongnya untuk terus tumbuh dan berkembang menuju perwujudan diri (self actualization), keterbukaan diri dan mengeksploitasi segala

\footnotetext{
${ }^{9}$ Dharma, Transformasi Pendidikan Memasuki Millenium Ketiga.
} 
potensi yang dimiliki. Manusia (peserta didik) bebas memilih aktifitasnya, namun bukan kebebasan yang tak berbatas, melainkan kebebasan yang dibatasi aturan hidup bersama. ${ }^{10}$

Oleh karena itu, reposisi wacana kemanusiaan dalam pendidikan harus digencarkan kembali untuk menyelamatkan masa depan anak didik. Tampaknya kekhawatiran ini juga dirasakan oleh pemerintah, sehingga dibuatlah konsep sekolah ramah anak sebagai salah satu solusi memperbaiki sistem pendidikan Indonesia. Dengan program ini, diharapkan anak didik menjadi individu yang merdeka, lebih kreatif, sadar akan potensinya, dan terlindung dari berbagai kekerasan di lingkungan sekolah.

\section{Sekolah Ramah Anak sebagai Konsep Pendidikan Anti Kekerasan}

Wacana pendidikan anti kekerasan ini diejawantahkan dalam Sekolah Ramah Anak (SRA), yaitu sekolah yang melindungi hak-hak anak secara terencana dan bertanggung jawab dalam setiap aspek kehidupannya. Asas pendidikan ini adalah non diskriminasi, hak hidup serta penghargaan terhadap anak. Hal ini diilhami dari pasal 4 UU No.23/2002 tentang perlindungan anak yang menyebutkan bahwa anak mempunyai hak untuk dapat hidup tumbuh, berkembang, dan berpartisipasi secara wajar sesuai harkat dan martabat kemanusiaan, serta mendapatkan perlindungan dari kekerasan dan diskriminasi.

Antara Sekolah Ramah Anak dan UU tersebut menunjukkan benang merah yang saling berhubungan yaitu memberikan hak

\footnotetext{
10 Hasan Langgulung, Kreatifitas Dan Pendidikan Islam (Jakarta: Pustaka AlHusna, n.d.), 230.
} 
tumbuh kembang dengan mempertimbangkan segala potensi yang dimiliki untuk senantiasa dikembangkan secara maksimal. ${ }^{11}$ Berpartisipasi secara wajar sesuai harkat dan martabatnya diwujudkan dengan kebebasan menyampaikan aspirasi dan keikutsertaan dalam kegiatan pendidikan yang merupakan kebutuhan anak dalam proses kehidupannya dan berpengaruh bagi masa depannya. Sedangkan perlindungan dari kekerasan dan diskriminasi diwujudkan dengan dalam suatu wadah pendidikan yang mengutamakan cinta kasih, persamaan hak dan kewajiban, serta memperhatikan kebutuhan anak didik.

Visi pendidikan ramah anak adalah terwujudnya anak yang cerdas, sehat, terampil dan berkualitas. Sedangkan misinya antara lain: melaksanakan PAIKEM ${ }^{12}$ berdasarkan iman dan takwa, meningkatkan profesionalisme pendidik dan tenaga kependidikan, melaksanakan pembiasaan berperilaku hidup sehat dan bersih, mengoptimalkan tumbuh kembang anak, dan melaksanakan pendidikan berbasis keterampilan. ${ }^{13}$

\footnotetext{
11 Dalam Islam, potensi tersebut dimaknai sebagai fitrah, yaitu suatu kemampuan (potensi terpendam) yang ada pada diri manusia sejak awal penciptaannya untuk selalu terikat terhadap nilai-nilai keimanan dan condong pada kebenaran. Fitrah tersebut antara lain fitrah beragama, berakal budi, berakhlak, kemerdekaan, sosial, kebenaran, dll. Lihat, Muhaimin, Pengembangan, 149-150.

12 PAIKEM menitikberatkan pada model pembelajaran yang mengaktifkan peserta didik, mengembangkan kreatifitas, dan dikemas secara menyenangkan untuk diterapkan pada peserta didik. Landasan pemikiran dicetuskannya PAIKEM berdasarkan pada tiga hal, yaitu: pertama, empat pilar pendidikan yang dicanangkan oleh UNESCO (learning to do, learning to know, learning to be, and learning to life together); kedua, pandangan konstruktifisme yang mengilhami perubahan konsep teacher centered menjadi student centered; ketiga, democratic teaching, yaitu suatu pemikiran menjadikan sekolah sebagai pusat pembelajaran yang demokrasi. Lihat, Hartono et.al., PAIKEM Pembelajaran Aktif Inovatif Kreatif Efektif dan Menyenangkan (Pekanbaru: Zanafa Publishing, 2012), 20-22.

${ }^{13}$ Herma Hermawati, "Pendidikan Ramah Anak," n.d.
} 
Beberapa hal di atas dapat dijadikan rujukan dasar dalam penyelenggaraan kegiatan pendidikan yang ramah anak. Keinginan tersebut dapat diaktualisasikan dengan menciptakan sekolah ramah anak dengan ciri-ciri sebagai berikut:

Pertama, sikap guru terhadap anak didik. Hal penting yang harus diperhatikan adalah bahwa setiap anak didik memiliki karakteristik yang berbeda dengan segala keunikannya. Perbedaan tersebut dikelompokkan ke dalam tiga aspek, yaitu perbedaan biologis, intelektual, dan psikologis. ${ }^{14}$ Tiga hal tersebut harus mendapat perhatian penuh dari guru agar kegiatan pendidikan menjadi lebih optimal dengan memberikan kasih sayang serta menjalankan norma agama dan budaya. ${ }^{15}$

Begitupun juga sikap anak didik terhadap guru, tidak seperti konsep pendidikan Barat yang hanya memperhatikan proses pendidikan pada saat berlangsung dan orientasi hasil setelah mendapat pengajaran, pendidikan Islam justru memperhatikan persiapan-persiapan dalam tahapan pra pendidikan agar kegiatan pendidikan menjadi lebih mudah dilaksanakan. Berbagai persiapan tersebut antara lain: sebelum

\footnotetext{
${ }^{14}$ Syaiful Bahri Djamarah, Psikologi Belajar (Jakarta: RinekaCipta, n.d.), 83.

15 Secara garis besar, guru memiliki lima peran terkait situasi dan kondisi yang dihadapinya. Kelima peran tersebut antara lain: pertama, menjadi inspirator yang mampu menggerakkan hati siswa untuk meneladani sosok guru tersebut. Kedua, menjadi motivator yang bisa menjadi sosok pembangkit semangat, pendorong potensi, dan penggerak aksi. Ketiga, menjadi fasilitator dengan mengakomodir aspirasi siswa selama bersifat positif dan konstruktif. Keempat, menjadi dinamisator dengan aktif mengikuti perkembangan zaman, memberikan pemikiran, ide, wacana, dan gagasan baru yang orisinil kepada anak didiknya. Dan kelima, menjadi konselor dengan cara berusaha memahami kejiwaan anak didik serta membantu menyelesaikan permasalahannya. Lihat, Jamal Ma'mur Asmani, 7 Tips Aplikasi PAKEM (Pembelajaran Aktif, Kreatif, Efektif, Dan Menyenangkan (Jogjakarta: Diva Press, n.d.), 167-181.
} 
belajar siswa hendaknya membersihkan hati dari segala sifat buruk seperti iri, dengki, sombong, dan tinggi hati; meluruskan niat untuk beribadah dan mendekatkan diri kepada Allah, bukan untuk menonjolkan diri; hendaknya menghormati guru, dan memiliki jiwa saling mencintai dan persaudaraan. ${ }^{16}$ Persiapan tahap awal ini menjadi sangat penting karena akan mempengaruhi warna proses pembelajaran dan output yang dihasilkan pasca kegiatan pembelajaran.

Kedua, metode pembelajaran. Kewajiban guru adalah menerapkan metode belajar yang inovatif dan beragam dengan menggunakan media pembelajaran yang cepat diserap anak, memotivasi anak untuk berpartisipasi serta mengembangkan kompetensi belajar berdasarkan learning by doing. Merujuk pada beberapa pendapat tokoh, pembelajaran yang menyenangkan akan lebih meningkatkan penerimaan anak didik terhadap materi pembelajaran. ${ }^{17}$ Pembelajaran yang menyenangkan (joyfull learning) adalah proses pembelajaran yang memiliki hubungan yang kuat antara guru dan siswa tanpa ada tekanan (not under pressure). ${ }^{18}$ Indikator peserta didik merasa cocok terhadap sekolah adalah sejauh mana ia merasa nyaman dan aman berada di sekolah itu. Joyfull learning bisa diaplikasikan dengan metode

\footnotetext{
16 M.Athiyah Al-Abrasyi, Dasap-Dasar Pokok Pendidikan Islam (Jakarta: Bulan Bintang, n.d.), 147-148.

17 Peter Kline mengemukakan "learning is most effective when it's fun" (belajar sangat efektif apabila menyenangkan). Berdasarkan ungkapan tersebut, menyenangkan mengandung pengertian: seluruh komponen fisik dan nonfisik bebas dari tekanan, berada dalam keadaan yang amat rileks, tidak ada sama sekali ketegangan yang mengancam diri di sudut-sudut terkecil fisik atau nonfisik. Lihat Hartono et.al, PAIKEM Pembelajaran Aktif Inovatif Kreatif Efektif Dan Menyenangkan (Pekanbaru: Zanafa Publishing, n.d.), 87.

18 Rusman, Model-Model Pembelajaran Mengembangkan Profesionalisme Guru (Jakarta: Rajawali Pers, n.d.), 326.
} 
edutainment dan penggunaan berbagai metode pembelajaran yang menarik. ${ }^{19}$ Dapat dikatakan bahwa Sekolah Ramah Anak bertumpu pada pembelajaran yang berpusat pada anak.

Ketiga, ruang kelas. Ruang kelas yang nyaman akan memberikan efek positif bagi anak didik. Penataan ruangan direncanakan secara tepat dan menarik, yaitu mempertimbangkan unsur kesehatan melalui pengaturan cahaya dan ventilasi ruangan yang cukup, memperhatikan unsur keindahan dengan pemilihan cat tembok yang segar serta menata lukisan dan karya siswa semenarik mungkin. ${ }^{20}$

Keempat, yang tidak kalah penting adalah rasa aman anak didik. Secara fisik, ia aman dari segala macam tindakan yang dapat mengancam jiwanya ataupun bebas dari berbagai bentuk eksploitasi. Secara psikis, ia bebas dari segala macam intimidasi.

\section{Peran Orang Tua Melalui School Parenting}

Orang tua memegang peranan yang sangat penting dalam mendukung pendidikan akhlak anaknya sejak dini, namun tidak semua orang tua menyadari hal tersebut. Tanpa sepengetahuan orang tua, apa yang dilakukan akan ditiru dan ditiru oleh anak. Untuk menghindari hal-hal yang tidak diinginkan, orang tua

19 Dewasa ini, edutainment (pembelajaran yang menekankan pada sisi hiburan) sangat diminati. Praktik edutainment dapat dilakukan dengan menyelipkan humor di tengah-tengah penyampaian materi atau humor yang dirancang untuk contoh-contoh faktual yang menarik sesuai materi yang dipelajari. Teknik bermain peran (role play) dan penggunaan multi media yang diiringi musik menyentuh hati merupakan alternatif dari pelaksanaan edutainment. Lihat, Moh Roqib, IImu Pendidikan Islam (Yogyakarta: Lkis, n.d.), 107.

20 Wina Sanjaya, Pengembangan Kurikulum dan Proses Pembelajaran (Bandung: San Grafika, n.d.), 132. 
harus memiliki latar belakang pendidikan yang baik. Apalagi, jika orang tua adalah guru, tentu mereka berilmu dan berilmu dalam mendidik anak-anaknya. ${ }^{21}$

Upaya mencerdaskan kehidupan bangsa tidak cukup jika hanya dibebankan kepada sekolah. Untuk itu perlu kerjasama yang sinergi antara orang tua dan sekolah melalui program school parenting. Program ini menekankan kerjasama antara orang tua dan sekolah untuk menyelesaikan berbagai permasalahan yang dihadapi terkait pola pengasuhan siswa, penanaman karakter, dan upaya memotivasi siswa untuk rajin belajar. $^{22}$

Sinergitas ini terjalin dalam bingkai kolaborasi pro aktif dan didasari semangat saling memiliki. Bentuk kerjasama orang tua dengan sekolah ditekankan pada beberapa keterlibatan, antara lain: 1) orang tua menciptakan budaya belajar, menata rumah sedemikian rupa agar anak betah belajar, melakukan pengasuhan yang efektif berdasar program pelatihan yang telah diberikan sekolah terhadap orang tua. 2) sekolah selalu menginformasikan perkembangan prestasi siswa, kesulitan belajar, hingga kecenderungan perilaku yang harus diwaspadai sebelum mengarah pada hal negatif. 3) kesadaran orang tua dan

\footnotetext{
${ }^{21}$ Rindhatus Jaujah and Luthfatul Qibtiyah, "Peran Orang Tua dalam Pendidikan Akhlak Anak Usia Dini," SYAIKHUNA: Jurnal Pendidikan dan Pranata Islam STAI Syichona Moh. Cholil Bangkalan 12, no. 1 (2021): 104.

22 Pola pengasuhan anak terdiri dari beberapa karakteristik. Pertama, authoritarian (otoriter). Kedua, indulgent (pembiaran oleh orang tua terhadap anak untuk melakukan apa yang mau). Ketiga, authoritative (pola demokratis, yaitu mengarahkan tanpa memaksa). Dan keempat, neglectful (pola asuh yang tidak jelas aturannya). Pola parenting yang cocok untuk anak-anak secara garis besar adalah pola demokratis karena sejalan dengan nilai agama, situasi kekinian, dan sejalan dengan teori pendidikan humanistik. Lihat, E. B Surbakti, No Title (Jakarta: PT. Elex Media, 2012), 7.
} 
masyarakat untuk berkolaborasi dalam upaya meningkatkan progresivitas pendidikan anak. 4) guru melakukan pendampingan terhadap orang tua dengan turut mengawasi belajar anak di rumah. Di samping itu juga membantu menumbuhkan kedekatan orang tua dan anak dengan memberikan tugas yang harus diselesaikan secara kolaboratif. 5) orang tua aktif dalam komite sekolah sehingga mampu memberikan kontribusi pemikiran dalam upaya memajukan sekolah. ${ }^{23}$

Ketika orang tua memahami cara mengasuh yang benar, ia dapat membangun komunikasi dengan anak untuk mencurahkan pendapat dan menciptakan suasana belajar ideal versi anak. Orang tua juga mampu memahami kesulitan belajar sekaligus problem pribadi anak dalam pergaulan, baik yang terjadi dalam pertemanan, interaksi dengan orang tua ataupun gurunya. Nilai positif yang dapat diambil adalah baik orang tua atau guru dapat mengetahui potensi anak, kebutuhan-kebutuhannya, sekaligus mengevaluasi proses interaksi dan pelayanan terhadap anak.

\section{Pemberlakuan Hukuman Psikopedagogik dalam Pendidikan Ramah Anak}

Dalam dunia pendidikan, teori pencegahan digunakan sebagai upaya preventif agar suatu permasalahan tidak berkembang. Menurut Emile Durkheim, teori ini menjadikan hukuman sebagai cara untuk mencegah pelanggaran terhadap aturan. Pemberian hukuman ini betujuan agar anak tidak

\footnotetext{
${ }^{23}$ Jane Brooks, The Process of Parenting, 527.
} 
mengulangi kesalahannya dan mencegah anak lain agar tidak meniru. $^{24}$ Lebih dari itu, hukuman juga berperan sebagai reinforcement negatif yang bisa menjadi alat motivasi apabila diberikan secara tepat dan bijak. ${ }^{25}$

Penerapan hukuman pada anak diklasifikasikan ke dalam empat kategori, yaitu hukuman fisik, hukuman verbal, isyarat non verbal, dan hukuman sosial. Hukuman fisik, berupa mencubit lengan, menjewer telinga, dan memukul. Hukuman bersifat verbal, seperti menegur, menyindir, dan memarahi. isyarat non verbal, seperti menunjukkan mimik wajah tidak suka. Dan hukuman sosial, berupa pengucilan (mengisolasi) dari pergaulan.

Dalam memberi hukuman, hendaknya menghindari hukuman fisik dan menyakiti secara psikis karena dapat menyebabkan anak tidak percaya diri dan kurang mempunyai inisiatif dan spontanitas. ${ }^{26}$ Padahal ketika anak berada pada posisi dihargai, dimengerti, dan guru dapat dengan bijak menunjukkan bahwa turut merasakan posisi anak, maka anak didik akan lebih mudah untuk diarahkan. Berkaca dari hal tersebut, hukuman bersifat mendidik (psikopedagogik) lebih direkomendasikan dalam kegiatan pendidikan.

Hukuman bersifat psikopedagogik yaitu sebuah konsep hukuman yang memiliki kriteria sebagai berikut: menggunakan pendekatan yang bisa menggugah pelaku mengakui kesalahan, mengembangkan pendekatan agar korban mau memaafkan,

\footnotetext{
${ }^{24}$ Emile Durkheim, Pendidikan Moral; Suatu Studi Teori Dan Aplikasi Sosiologi Pendidikan (Jakarta: Erlangga, n.d.), 116.

25 Sardiman, Interaksi Dan Motivasi Belajar Mengajar (Jakarta: PT Raja Grafindo Persada, 2010).

${ }^{26}$ Zakiah Daradjat, Kesehatan Mental (Jakarta: Gunung Agung, n.d.), 84.
} 
menggugah hati pelaku untuk bertanggung jawab atas segala dampak pelanggarannya, pertanggung jawaban pelaku harus memenuhi unsur penyelesaian masalah dan berdampak timbulnya pengetahuan dan sikap baru yang lebih positif, hukuman yang dibebankan tidak menimbulkan dampak psikologis yang berat serta menurunkan harkat dan martabat kemanusiaan, monitoring sikap pelaku pasca pemberian hukuman, dan memberi kepercayaan pada pelaku untuk menjadi pelopor perilaku disiplin dan bertanggung jawab. ${ }^{27}$

Adapun upaya preventif terhadap upaya pelanggaran peraturan oleh anak didik, maka guru hendaknya memberikan kebebasan yang bersifat tidak mutlak dengan memberikan batasan tertentu sesuai dengan kebutuhan. Mengingat anak masih berada dalam proses perkembangan pemikiran dan kepribadiannya belum kuat. Ia belum matang untuk menghadapi masalahnya sehingga memerlukan pendampingan dalam mencari alternatif jalan terbaik.

Dalam ilmu pendidikan Islam, cara mendidik seperti ini disebut thariqah al-dimuqratiyyah al-dla'ifiyyah (metode pendidikan demokrasi yang fleksibel). ${ }^{28}$ Dalam artian ada saatnya pendidik membiarkan anak didik melakukan aktivitas sesuai keinginannya namun tetap dalam pengawasan. Sekali

\footnotetext{
27 Yusi Riksa Yustiana, Pengembangan Model Sekolah Ramah Anak: Impelementasi Pendekatan Restorative Justice dalam Menangani Peserta Didik yang Melakukan

Pelanggaran

Aturan Sekolah,http://file.upi.edu/Direktori/FIP/JUR._PSIKOLOGI_PEND_DAN_BIMBI NGAN/196611151991022YUSI_RIKSA_YUSTIANA/Artikel,_modul._penelitian/Sekolah_Ramah_anak.pdf, diakses pada tanggal 7 Nopember 2014.

${ }^{28}$ Nur Ukhbiyati, IImu Pendidikan Islam (Bandung: CV. Pustaka Setia, n.d.), 128-129.
} 
waktu guru harus membatasi pergaulan dan perilaku anak agar tidak terjerumus dalam kesalahan. Di lain waktu pula guru berada di tengah-tengah anak untuk memberi semangat, teladan, dan menginspirasi untuk menjadi sosok yang selalu beristiqamah dalam kebenaran.

\section{Positif-Negatif Pendidikan Ramah Anak dan Berbagai Hambatannya}

Sebaik apapun sebuah rancangan program pasti memiliki kekurangan walaupun dalam persentase yang kecil. Kekurangan tersebut akan memberikan dampak negatif dalam pengaplikasiannya, baik karena sasaran program yang kurang tepat ataupun kesalahan dalam ranah operasionalnya.

Berbagai dampak positif dari pelaksanaan pendidikan ramah anak antara lain: anak bebas berkreasi sesuai bakat dan minatnya, terjadinya situasi pembelajaran yang student centered dan menyenangkan, menjauhkan anak didik dari tindak kekerasan dalam proses pendidikan, baik sebagai pelaku ataupun korban, serta memperlakukan anak didik secara manusiawi sesuai dengan tingkat umur dan psikologisnya.

Sedangkan dampak negatif dari pemberlakuan pendidikan ramah anak antara lain: anak didik tidak mematuhi peraturan dan cenderung nakal karena kesalahan persepsi terhadap makna kebebasan yang diberikan kepadanya. Kebebasan ini sering dimaknai sebagai pembiaran kebebasan berkreasi dan berekpresi seluas-luasnya tanpa batas dan aturan. Hal ini juga bisa disebabkan karena guru tidak menguasai psikologi perkembangan siswa, metode dan strategi pembelajaran yang 
baik, guru juga kurang memiliki seni berkomunikasi yang baik dengan anak didik. Selain itu, pemberian hukuman dianggap sebagai tindakan kekerasan terhadap anak didik, padahal secara psikologis, pemberian hukuman akan memberikan efek jera bagi pelaku pelanggaran.

Adapun berbagai hambatan yang seringkali dialami dalam pemberlakuan pendidikan ramah anak antara lain: pertama, dalam beberapa lembaga pendidikan Islam khususnya pesantren, masih terdapat beberapa guru/kyai yang kurang senang menerapkan pembelajaran active learning. Situasi pembelajaran masih terkesan satu arah (teacher centered), murid diharuskan duduk tenang, tidak boleh terlalu banyak bergerak, dilarang menatap guru, bahkan dilarang bertanya. Semua hal tersebut apabila dilanggar akan mendapat hukuman keras dari kyai karena dianggap su'u al-adab. Hukuman yang diberikanpun terkadang mencerminkan sesuatu yang tidak layak jika dipandang dalam sudut pandang pendidikan, seperti membentak, melempar sandal, hingga tamparan. Namun seringkali perbuatan tersebut dianggap wajar dan dimaklumi dengan harapan memperoleh barokah sang kyai.

Kedua, kurangnya dukungan dari keluarga dan masyarakat. Dalam beberapa wilayah terdapat suatu daerah yang identik dengan karakteristik tertentu, misalnya kawasan prostitusi, perjudian, hingga perkelahian. Berbagai materi dan media yang sebenarnya tidak pantas diperlihatkan kepada anak, seperti minuman keras, senjata tajam, dan permainan judi, justru menjadi pemandangan biasa sehari-harinya. Hal ini akan berdampak pendidikan yang ditanamkan di sekolah akan 
menguap begitu saja, mengingat anak didik lebih banyak berinteraksi dalam kehidupan keluarga dan masyarakat daripada di sekolah. Di samping itu, anak didik seringkali mengalami split personality (kepribadian yang terpecah), karena ketidak sesuaian antara fenomena di sekolah yang mengajarkan nilainilai kebaikan, namun dalam kehidupan nyata, mereka menjumpai hal-hal yang tidak sesuai dengan ajaran kebaikan tersebut. $^{29}$

Ketiga, guru dan anak didik tidak menyadari peran dan posisi masing-masing. Adakalanya guru kurang memiliki kemampuan mengolah kelas sehingga anak didik menjadi jenuh, guru kurang bisa mengendalikan anak didik melalui pendekatan yang bersahabat karena terpaku pada anggapan bahwa tugas utama guru adalah mengajar dan tidak perlu dekat dengan siswa agar tidak menjadi lancang terhadap guru. Begitu pun anak didik terkadang terlalu asik dengan dunianya, enggan berkompromi dengan keadaan sehingga tidak mudah untuk diarahkan.

\section{KESIMPULAN}

Sekolah Ramah Anak timbul karena kekhawatiran klimaks atas permasalahan kompleks yang terjadi dalam dinamika pendidikan Indonesia. Dalam tataran konsep, sekolah ramah anak telah memberikan pernyataan tegas bahwa pendidikan harus memanusiakan anak didik, dan bahwa anak didik adalah manusia yang bebas mengaktualisasikan bakat yang dimiliki

29 Baharuddin Muh. Makin, Pendidikan Humanistik (Konsep, Teori Dan Aplikasi Praksis Dalam Dunia Pendidikan (Yogyakarta: Ar-Ruzz Media, n.d.), 11-12. 
berdasarkan keunikan dan perbedaan antar individu. Tugas kita bersama untuk mewujudkannya dalam tataran operasional praktis, karena dengan pendidikan ramah anak, anak didik akan mendapat haknya sebagai manusia sesuai tingkatan umurnya. Mereka tidak lagi menjadi miniatur orang dewasa atau terancam fisik dan psikisnya.

\section{DAFTAR PUSTAKA}

Al-Abrasyi, M.Athiyah. Dasap-Dasar Pokok Pendidikan Islam. Jakarta: Bulan Bintang, n.d.

Asmani, Jamal Ma'mur. 7 Tips Aplikasi PAKEM (Pembelajaran Aktif, Kreatif, Efektif, Dan Menyenangkan. Jogjakarta: Diva Press, n.d.

Danim, Sudarwan. Agenda Pembaruan Sistem Pendidikan. Yogyakarta: Pustaka Pelajar, n.d.

Daradjat, Zakiah. Kesehatan Mental. Jakarta: Gunung Agung, n.d.

Dharma, Tim Penyusun Universitas Sanata. Transformasi Pendidikan Memasuki Millenium Ketiga. Yogyakarta: Kanisius, n.d.

Djamarah, Syaiful Bahri. Psikologi Belajar. Jakarta: RinekaCipta, n.d.

Durkheim, Emile. Pendidikan Moral; Suatu Studi Teori Dan Aplikasi Sosiologi Pendidikan. Jakarta: Erlangga, n.d.

et.al, Hartono. PAIKEM Pembelajaran Aktif Inovatif Kreatif Efektif Dan Menyenangkan. Pekanbaru: Zanafa Publishing, n.d.

Friere, Paulo. Pendidikan Kaum Tertindas. Jakarta: LP3ES, n.d.

Hermawati, Herma. "Pendidikan Ramah Anak," n.d.

Jaujah, Rindhatus, and Luthfatul Qibtiyah. "Peran Orang Tua Dalam Pendidikan Akhlak Anak Usia Dini." SYAIKHUNA: Jurnal Pendidikan dan Pranata Islam STAI Syichona Moh. Cholil Bangkalan 12, no. 1 (2021).

Khalik, Abd etal. Pemikiran Pendidikan Islam. Yogyakarta: Pustaka Pelajar, n.d.

Laisa, Emna. "Optimalisasi Pendidikan Agama Islam Di Sekolah Melalui Pengembangan Budaya Religius (Studi Pada SMK 
Darul Ulum Bungbungan Bluto Sumenep"." Islamuna 3, no. 1 (n.d.).

Langgulung, Hasan. Kreatifitas Dan Pendidikan Islam. Jakarta: Pustaka Al-Husna, n.d.

Muh. Makin, Baharuddin. Pendidikan Humanistik (Konsep, Teori Dan Aplikasi Praksis Dalam Dunia Pendidikan. Yogyakarta: Ar-Ruzz Media, n.d.

Piaget, J. Science of Education and The Psychology of The Chil. New York: Viking, n.d.

Roqib, Moh. Ilmu Pendidikan Islam. Yogyakarta: Lkis, n.d.

Rusman. Model-Model Pembelajaran Mengembangkan Profesionalisme Guru. Jakarta: Rajawali Pers, n.d.

Sanjaya, Wina. Pengembangan Kurikulum Dan Proses Pembelajaran. Bandung: San Grafika, n.d.

Sardiman. Interaksi Dan Motivasi Belajar Mengajar. Jakarta: PT Raja Grafindo Persada, 2010.

Surbakti, E. B. No Title. Jakarta: PT. Elex Media, 2012.

Ukhbiyati, Nur. IImu Pendidikan Islam. Bandung: CV. Pustaka Setia, n.d. 